\section{"Erosion of UK research on agriculture and food must end"}

\section{London}

Curs in government support for nearmarket research were severely criticised last week by the House of Lords Select Committee on Science and Technology. In a report on agriculture and food research in Britain, it said the government should reassess the list of projects defined as near-market so as not to include research which is in the public good, such as animal health and welfare, food safety and quality standards and protection of the environment.

The committee also recommends that the proposed timescale of three years for the transfer to industry of support for near-market research should be extended to five. Savings made in this exercise should be used to support basic and strategic research.

Although some of the rationalization in the Agricultural and Food Research Council (AFRC) has been to good effect, the cuts and the uncertainty about future

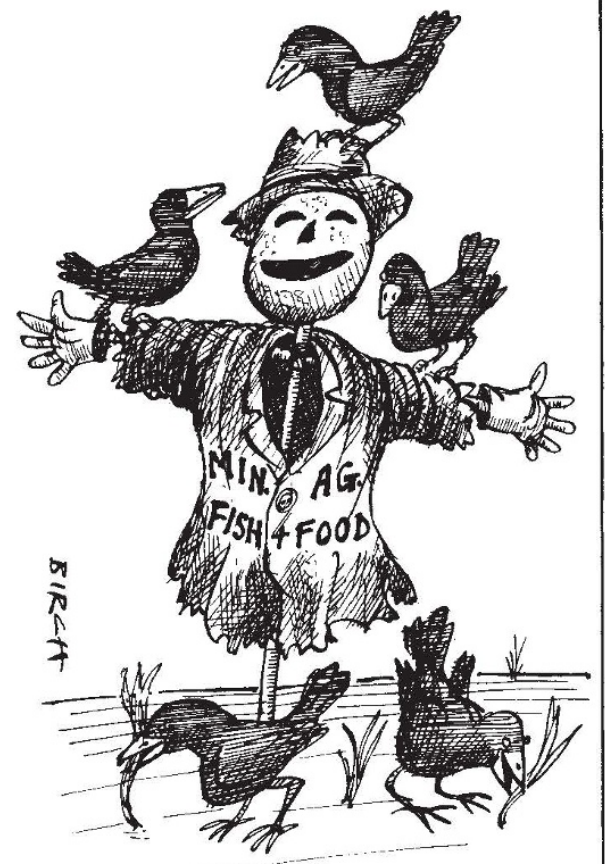

levels of support have caused instability and severe problems in the research community, says the committee. Industry should make a major contribution to the cost of research aimed at increasing industrial profitability and competitiveness, but the committee warns that if a sound research base is not maintained through public support, then commissions are likely to go overseas.

The research base in agriculture and food should not be reduced further, says the committee. A period of stability would lead to a reversal of the damaging trend towards more short-term appointments. Such appointments are appropriate when projects are of fixed length, but should not be used simply because future finances are uncertain. In the AFRC, the number of short-term appointments is already too high, it says

The Ministry of Agriculture, Fisheries and Food comes under searing criticism from the committee. Scientific knowledge has had little impact on the ministry's policy, it says; because of the inadequate number of staff and an inappropriate structure, interaction with researchers is inadequate, as is the provision of proper guidance and advice.

The committee also criticizes the ministry's performance as a customer for research. Although it supports the principle that applied research should be supported on a customer contractor basis, its performance has been poor. Because of

\section{Washington}

AN old idea for producing tritium for nuclear warheads is gaining new favour in the United States. A report compiled by scientists and engineers at Los Alamos National Laboratory, Brookhaven National Laboratory and Westinghouse Hanford Company, which is soon to be submitted to the Department of Energy (DoE), advocates construction of a huge linear proton accelerator for the production of tritium; it may be powered by excess electricity from hydroelectric sources.

The closure last spring of the ageing Savannah River reactors, the sole US source of tritium for nuclear bombs, forced DoE to consider alternative production methods. Last summer, the department announced plans for two new production reactors, a heavy-water reactor at Savannah River and a modular hightemperature gas reactor at the Idaho National Engineering Laboratory (see Nature 334, 558; 18 August 1988). The DoE budget request for 1990 , compiled by the former Reagan administration, includes some money to start building the reactors. But a draft of the Los AlamosBrookhaven-Westinghouse report claims that accelerator production of tritium would be cheaper and safer.

The principle of accelerator production is simple. A beam of high-energy protons is fired at a lead target to produce highenergy neutrons which in turn hit a lithium target which emits helium and tritium. this, the committee recommends that funds transferred in 1975-76 to the ministry from the then Agriculture Research Council should be returned to the AFRC, or given to the proposed Natural Resources Research Council (NRRC). (In its interim report on agriculture and food, the committee recommended that a new council, the NRRC, be formed from a merger of the AFRC with the Natural Environmental Research Council.) The money - about $£ 27$ million - would be more productive as part of the AFRC or NRRC budget, says the committee.

The Biotechnology Directorate of the Science and Engineering Research Council is praised by the committee, but it says that the other research councils should be involved in the directorate's activities. There should be more joint initiatives, for which proposals should come from a new advisory group. It says that more research is needed on plant biochemistry and physiology, and it recommends more research on nutrition and forestry.

Christine McGourty

\title{
US plan for proton accelerator to produce tritium for warheads
}

The same approach is used in production reactors where the source of the neutrons is nuclear fission.

Wolfgan Panofsky, emeritus director of the Stanford Linear Accelerator Center, says the proposed accelerator is "well within the capabilities of present technology". In fact, he says, a prototype accelerator with a proton beam current comparable to that proposed $(250$ milliamps) was built at Livermore for the production of plutonium and tritium in 1949. Panofsky also agrees with the report's conclusion that the accelerator system will produce less radioactive waste than a production reactor.

But a key problem will be providing the gigawatt of electricity the accelerator will need. Building a new nuclear reactor to supply the accelerator would defeat the original purpose. But Pierre Grand of Brookhaven, who helped to compile the report, says that Bonneville Power Administration in Washington state, where advocates hope to site the accelerator, has tentatively said it can provide about $900 \mathrm{MW}$ from excess hydroelectric generating capacity.

Another open question is cost. The report estimates that the $1.6-\mathrm{GeV}$ facility will cost about $\$ 2,300$ million with annual running expenses of $\$ 250$ million - considerably cheaper than the estimated $\$ 6,800$ million required for new production reactors. But Grand emphasizes that these figures are "very preliminary".

David Swinbanks 